\title{
Cell lysis and release of particulate polysaccharides in extensive marine mucilage assessed by lipid biomarkers and molecular probes
}

\author{
Franco Baldi ${ }^{1, *}$, Andrea Minacci ${ }^{1}$, Alain Saliot ${ }^{2}$, Laurence Mejanelle ${ }^{2}$, \\ Patricija Mozetic ${ }^{3}$, Valentina Turk ${ }^{3}$, Alenka Malej ${ }^{3}$ \\ ${ }^{1}$ Department of Environmental Biology, University of Siena, Via P. A. Mattioli 4, I-53100 Siena, Italy \\ ${ }^{2}$ Laboratoire de Physique et Chimie Marines de l'Université Pierre et Marie Curie, Observatoire des Sciences de l'Univers, \\ URA CNRS 2076, 4 Place Jussieu, F-75252 Paris Cedex 05, France \\ ${ }^{3}$ National Institute of Biology, Marine Biological Station Piran, Fornace 41, SI-6330 Piran, Slovenia
}

\begin{abstract}
During the massive muclage event in the northern Adriatic Sea in July 1991 samples of macroaggregate were fixed in different ways: with formaldehyde, deep frozen and freeze-dried. Conventional microscopy (light and epifluorescence) revealed different autotrophic species embedded in gelatinous matrix. Cyanobacteria and heterotrophic bacteria were also identified. Scanning confocal laser microscopy (SCLM) and fluorescent molecular probes (the lectins concanavalin A and UEA-I) showed wall-free cytoplasm and particulate polysacchandes leaking from the envelopes of broken cells in the matrix. The extensive cell lysis was supported by the observation of cytoplasm-free cytoskeletons, stained by the molecular probe phalloidin. High concentrations of triglycerides $(30 \%$ of total lipids) and free fatty acıds (22\%) along with very low concentrations of phospholipids (2\%) also indicated massive cell degradation in freeze-dried material. The mucilage observations were compared with those of a natural plankton community grown under high nutrient conditions using the same techniques. Free polysaccharides were observed as globular flocs (marine snow) during in situ enrichment experiments and intracellular polysaccharides as carbon storage materials in autotrophic organisms. No strings, filaments, layers, cell lysis or lipid classes indicating strong cell biodeterioration were observed in a 1 mo controlled experiment during an algal bloom.
\end{abstract}

KEY WORDS: Marine mucilage Polysaccharides Molecular probes - SCLM - Lipid biomarker Adriatic Sea

\section{INTRODUCTION}

The exceptional event of large floating amounts of mucilage in the northern Adriatic Sea attracted public attention in 1988. The sea was covered with mucoid scum which prevented tourists from bathing. It was an economic disaster which was repeated in 1989 and 1991. A similar widespread event occurred in 1949. Before the tourist era, fishermen, local newspapers and scientific journals recorded similar events back as far as 1729 (Fonda Umani et al. 1989). The phenomenon

\footnotetext{
•E-mail: baldi@unisi.it
}

has been described in detail by Stachowitsch et al. (1990). The periodicity of the mucilage phenomenon was recently calculated over $120 \mathrm{yr}$, and indicated an average cycle of $5.74 \mathrm{yr}$. It was concluded that there was a $50 \%$ probability that the next event would take place in 1996, and a $90 \%$ probability that it will recur in 2005-2006 (Vollenweider et al. 1995).

Aggregation and massive sedimentation of phytoplankton in marine and limnetic environments have been extensively studied in field and controlled experimental systems since these processes are of considerable significance in the global carbon cycle (Alldredge \& Jackson 1995). Empirical evidence and theoretical considerations based on coagulation theory (Kiørboe \& 
Hansen 1993) indicate the importance of phytoplankton stickiness, which varies from species to species and gel-like transparent exopolymer particles (TEP) in aggregation processes (Alldredge et al. 1993). None of these findings satisfactorily explains the mucilage phenomenon in the northern Adriatic, although diatoms are implicated as the main source of mucilage.

Several hypotheses to explain the origin of mucilage phenomena in the northern Adriatic have been proposed. (1) The first is that large floating mucilage is marine snow aggregated and consolidated to form a self-sustaining mucilage community that resists breakup (Fogg 1995). (2) Two factors leading to excessive marine snow and mucus were identified by Herndl (1992): high photosynthetic extracellular release during summer, probably stimulated by severe $N$ and P limitation (Myklestad 1995), and development of a strong pycnocline preventing material flux to the bottom. (3) Degobbis et al. (1995) related the mucilage phenomenon to modifications in environmental conditions in the northern Adriatic and changes in community structure (increased diatom contribution, change in doninant species\}. (4) The most recent hypothesis is that high $\mathrm{C} / \mathrm{P}$ and slow-to-degrade organic matter is produced by sustained high rates of primary production and efficient bacterial phosphorus remineralization in preference to carbon, while aggregation is enhanced by mucus from bacterial capsules (Azam 1996). These hypotheses are not mutually exclusive and may even complement one another

The aim of our paper was to shed new light on the mucilage phenomenon using novel microscope techniques and molecular probes for polysaccharides and other important molecular targets. The role of polysaccharides is commonly recognized in extensive mucilage events (Marchetti et al. 1989, Murano et al. 1993, Faganeli et al. 1995). The lipid classes of the mucilage were also analyzed since only fatty acids had been analyzed so far (Viviani et al. 1995) Lipids are useful to describe the status of mucus aggregates and they can provide an insight into biogeochemical processes (Wakeham \& Lee 1989, Saliot et al. 1991). Lipid partitioning was also used to support microscope observations. To aid interpretation of our results for large floating mucilage, a comparison was made with the results of an in situ nutrient-enrichment experiment using a natural plankton community. Various hypotheses to explain the extensive cell lysis are discussed.

\section{MATERIALS AND METHODS}

Mucilage and seawater sampling. Seawater samples were collected with a 51 Niskin sampler at offshore stations in the eastern part of the Gulf of Trieste (north- ern Adriatic), during summer 1991 (June-August). In July, mucilage samples were collected at different depths by SCUBA at the same stations using a large syringe. Samples were fixed with borate-buffered formalin (1.5\% final concentration) and/or deep frozen. All analyses were carried out within 3 mo except for confocal laser microscopy and lipid analysis which were performed after 3 and $4 \mathrm{yr}$

Enrichment experiment. Seawater for the enrichment experiment was sampled at an offshore station $1 \mathrm{~m}$ below the surface in April 1995, filtered through a $200 \mu \mathrm{m}$ pore size plankton net to remove larger grazers, and dispensed into $8 \mathrm{l}$ polycarbonate containers. One bottle served as a control. A mixture of inorganic nutrients was added to a second bottle to a final concentration approximately 10 times higher than background. The bottles were incubated at a depth of $2 \mathrm{~m}$ in the sea (exposure to daylight, water temperature between 12 and $13^{\circ} \mathrm{C}$ ). Experimental details have already been reported (Malej et al. 1996). In these experiments all analyses including lipids and confocal microscopy were performed within $3 \mathrm{mo}$

Light and epifluorescence microscopy. The formalin-preserved samples of mucilage and seawater samples from the enrichment experiment were examined by light microscope. The mucilage was observed again in 1994 and 1995 for differences caused by annual storage. The phytoplankton composition was determined using the sedimentation technique of Utermöhl (1958), and autofluorescent cyanobacteria were counted under green excitation light (Takahashi et al. 1985). Samples for bacterial counts were stained with DAPI (4', 6-diamidino-2-phenylindole) according to the protocol of Porter \& Feig (1980) and examined by epifluorescence microscopy.

Molecular probe analysis. A $0.3 \mathrm{ml}$ aliquot of mucus was incubated for $1 \mathrm{~h}$ with $5 \mu$ l of Con-A-FITC (concanavalin A from Canavalia ensiformis conjugated with $1 \mathrm{mg} \mathrm{ml}^{-1}$ fluorescein isothiocyanate, C 7642 ; Sigma) solution in phosphate buffer (Neu \& Marshall 1991, Gabius \& Gabius 1993). This lectin specifically binds different carbohydrate residues: $D(+)$-glucose, $\mathrm{N}$-acetyl-D-glucosamine, $\mathrm{D}(+)$-mannose and methyl a-D-mannopyranoside (Haugland 1992, Gabius \& Gabius 1993). Another lectin, UEA-1 conjugated with fluorescein (L-9006; Sigma) from Ulex europeus that specifically binds sugar residues of fucose (Neu \& Marshall 1991), was used as control for fluorescence distribution. To control the specificity of the lectins, commercial crystals of amylopectin, which consist of layers of $\mathrm{D}$-glucose linked by $\alpha(1,4)$ and $4 \%$ branched $\alpha(1,6)$ bonds, were soaked for $5 \mathrm{~h}$ in seawater from the Gulf of Trieste. The 2 lectins were incubated with amylopectin granules ( $5 \mathrm{mg} \mathrm{m} \mathrm{ml}^{-1}$ ) according to the protocol for mucilage samples. 
To reveal stained neutral lipids in the cells, $0.5 \mathrm{ml}$ of mucilage was incubated with $10 \mu \mathrm{l}$ of $1 \mathrm{mg} \mathrm{ml}^{-1}$ Nile red (N-3013, Sigma) standard solution in acetone (Greenspan \& Fowler 1985). The sample was exposed for 5 min and then analyzed by scanning confocal laser microscopy (SCLM).

To localize cell-free cytoskeleton proteins of F-actin from the lysis of marine cells, a $10 \mu \mathrm{l}$ aliquot of $1 \mathrm{mg}$ $\mathrm{ml}^{-1}$ solution of phalloidin conjugated with FITC (Molecular Probes Inc.) was used. The mucus sample was incubated with the molecular probe for $2 \mathrm{~h}$.

SCLM analysis. A Nikon Microphot microscope was mounted on a confocal laser (MRC-500; Bio-Rad Microscience Division) to obtain images of mucilage samples. The microscope was equipped with $\mathrm{a} \times 60,1.4$ numerical aperture (NA) oil immersion lens (Nikon Corp.). A krypton-argon laser with maximum emission lines at $488 \mathrm{~nm}$ was used to measure the excitation source of the fluorescein conjugated lectins, Nile red and F-phalloidin. Images were obtained with a BioRad photomultiplier pickup device and integrated and digitized with a Kalman true-running-average filter (Wolfaardt et al. 1994). The recorded video images $(512 \times 768$ pixels $)$ were displayed on a 7 " flat, blackand-white, high-resolution, $16 \mathrm{MHz}$ video display screen (VM 1710; H. Lucius \& Baer, Geretsried, Germany) and photographed with a Nikon F-301 camera equipped with a $105 \mathrm{~mm}$ lens. Image analysis of the recorded sections of the samples was carried out with Comos Bio-Rad software.

Iatroscan lipid analysis. Total lipid extract was analyzed for lipid class composition with an Iatroscan MKV TLC/FID analyzer (Iatron Laboratories, Japan). Samples and standards were spotted in triplicate on SIII Chroma-rods with a 1 ul automatic syringe (SES, Germany). A stepwise method was used to separate the different lipid classes, with 3 consecutive developing solvent systems of increasing polarity. After each development, partial scans of the Chroma-rods were performed to quantify the lipid classes eluted away from the initial spot (Volkman et al. 1986, Laureillard et al. 1997). The flame ionization detector (FID) was operated with a hydrogen flow of $160 \mathrm{ml} \mathrm{min}^{-1}$, an air flow of $1800 \mathrm{ml} \mathrm{min}^{-1}$, and the 'rods' were scanned in $30 \mathrm{~s}$. Peak areas were integrated using 'Boreal' software (JMBS, Grenoble). Lipid classes were identified according to their retention times and quantified using external calibration. Calibration curves were constructed for each lipid class with loads in the range 0.2 to $3.5 \mu \mathrm{g}$. This analytical procedure allows quantification of 13 lipid classes: hydrocarbons, wax esters and steryl esters, methyl esters, free fatty acids, triacylglycerols, ketones, alcohols, sterols, diacylglycerols, chlorine pigments, monoacylglycerols and polar lipids (mainly phospholipids and glycolipids). The precision in absolute weight is about 5 to $10 \%$ of the lipid class weight, and the standard deviation accounts for about 1 to $5 \%$ of the relative abundance of any lipid class.

\section{RESULTS}

\section{Light and epifluorescence microscopy}

The analysis of fresh and formalin-preserved mucilage using light and epifluorescence microscopy showed that the most numerous eukaryotic organism was the diatom species Cylindrotheca closterium followed by Rhizosolenia alata f. gracillima and $R$. fragilissima. C. closterium was also rather abundant in the water samples collected before the development of visible mucilage, as well as in the enrichment experiment (Table 1). In contrast, diatoms Pseudonitzschia delicatissima comp. and Skeletonema costatum reached high abundance in the enrichment experiment but were rare or absent in the mucilage. Two species of dinoflagellates were abundant in the early stage of visible mucilage (July 11) but were not recorded later (July 24). Synechococcus-like cyanobacteria and heterotrophic bacteria developed well within the mucilage (Table 1). Microscopic observations of procaryotes indicated that they were more abundant in mucus than in seawater and in the enrichment experiment. Other organisms and particles like coccolithophorids, dead and decaying copepods, fecal pellets and dinoflagellate thecae were regularly found.

All organisms and particles were generally embedded in a dense mucus matrix. Primulin staining of this matrix indicated polysaccharide material in the form of fibrils and globules.

The same formalin-stored sample of mucilage was analyzed 4 yr later using the same techniques to reveal possible changes. The main difference from freshly analyzed material was faded autofluorescence. When the sample was stained with primulin, it had the same appearance, without any major changes in the morphological structure of the microorganisms embedded in the mucoid matrix.

\section{Confocal microscope observations}

The mucilage, stored in formalin at $4{ }^{\circ} \mathrm{C}$, was also analyzed 3 and 4 yr later by confocal microscopy using the lectins Con-A and UEA-I to specifically determine the carbohydrate residues. The images presented here are from many observations of different specimens of the mucilage of 1991. Con-A showed that marine eukaryotes embedded in the mucilage contained enormous amounts of intracellular polysaccharide (IPS) 
Table 1. Optical microscopy: list of organisms and particles found in seawater samples before development of visible mucilage in the 1991 muclage and at the end of the 1995 enrichment experiment. nd: not detected; $(-)$ absent, $(+)$ present, $(++)$ abundant $(+++)$ very abundant, $(++++)$ dominating species

\begin{tabular}{|c|c|c|c|c|}
\hline Organisms and particles & $\begin{array}{c}\text { Seawater } \\
\text { June } 24 \\
\text { (cells } \times 1^{-1} \text { ) }\end{array}$ & $\begin{array}{c}\text { Mucilage } \\
\text { July } 11\end{array}$ & $\begin{array}{l}\text { Mucilage } \\
\text { July } 24\end{array}$ & $\begin{array}{c}\text { Seawater } \\
\text { enrich. expt } \\
\text { (cells } l^{-1} \text { ) }\end{array}$ \\
\hline \multicolumn{5}{|l|}{ Diatoms } \\
\hline Cerataulina pelagica & $1.6 \times 10^{3}$ & - & - & nd \\
\hline Chaetoceros spp. & $2.7 \times 10^{3}$ & - & - & $1.2 \times 10^{7}$ \\
\hline Cyclotella sp. & $5.0 \times 10^{4}$ & + & + & $2.8 \times 10^{5}$ \\
\hline Cylindrotheca closterium & $2.1 \times 10^{3}$ & +++ & ++++ & $3.6 \times 10^{6}$ \\
\hline Guinardia flaccida & nd & + & - & nd \\
\hline Hemiaulus hauckii & nd & - & + & nd \\
\hline Leptocylindrus minimus & $2.3 \times 10^{4}$ & - & - & nd \\
\hline Pseudonitzschia delicatissima comp. & $1.5 \times 10^{4}$ & - & - & $5.8 \times 10^{8}$ \\
\hline Rhizosolenia alata f. gracillima & $8.6 \times 10^{3}$ & ++ & + & nd \\
\hline R. fragilissima & $1.4 \times 10^{4}$ & + & + & $2.8 \times 10^{5}$ \\
\hline Skeletonema costatum & nd & - & + & $8.3 \times 10^{7}$ \\
\hline Benthic diatoms & nd & + & - & nd \\
\hline \multicolumn{5}{|l|}{ Dinoflagellates } \\
\hline Ceratium fusus & nd & + & + & nd \\
\hline Dinophysis rotundata & nd & - & + & nd \\
\hline D. ovum & nd & + & - & nd \\
\hline Glenodinium sp. & $5.9 \times 10^{3}$ & - & - & nd \\
\hline Gonyaulax poiyedra & nd & - & + & nd \\
\hline Gymnodinium spp. & $3.6 \times 10^{4}$ & - & - & nd \\
\hline Prorocentrum compressum & nd & + & - & nid \\
\hline P. micans & $0.53 \times 10^{3}$ & ++ & - & nd \\
\hline P. minimum & $0.53 \times 10^{3}$ & ++ & - & $2.8 \times 10^{5}$ \\
\hline Cysts & nd & + & - & nd \\
\hline \multicolumn{5}{|l|}{ Coccolithophorids } \\
\hline Emiliania huxleyi & $1.3 \times 10^{4}$ & + & + & $1.4 \times 10^{5}$ \\
\hline Pontosphaera nigra & nd & + & + & nd \\
\hline Syracosphaera pulchra & $1.6 \times 10^{3}$ & + & + & nd \\
\hline \multicolumn{5}{|l|}{ Other } \\
\hline Microflagellates & $5.6 \times 10^{5}$ & - & - & $3.3 \times 10^{7}$ \\
\hline Cyanobacteria & $0.5 \times 10^{7}$ & +++ & +++ & $0.5 \times 10^{6}$ \\
\hline Heterotrophic bacteria & $0.5 \times 10^{9}$ & ++++ & ++++ & $0.9 \times 10^{9}$ \\
\hline Copepods & nd & + & - & nd \\
\hline Fecal pellets & nd & ++ & + & nd \\
\hline Yeasts & nd & + & - & nd \\
\hline Pollen & nd & + & + & nd \\
\hline Shellfish larvae & nd & - & + & nd \\
\hline \multicolumn{5}{|l|}{ Dead organisms } \\
\hline Undetermined copepods & nd & - & + & nd \\
\hline Dinoflagellate thecae & nd & ++ & ++ & nd \\
\hline Empty diatom frustulae & nd & - & - & ++ \\
\hline
\end{tabular}

particles. In our samples, we observed that Con-AFITC bound to polysaccharides of different size and morphology. An example is shown in Fig $1 \mathrm{a}$, which was obtained from eleven $0.8 \mu \mathrm{m}(z)$ optical sections, to a total thickness of $8.8 \mu \mathrm{m}$. The image shows an autotrophic cell stuffed with IPS granules. A light transmission image (not shown) showed that this carbon storage material had partially leaked out of the cell.

Another type of fluorescence image produced by Con-A distribution (Fig. 1b) was the filamentous exo- polysaccharide (EPS) from marine microorganisms stuffed with IPS granules. It was common to observe all types of organisms in the mucilage filled with these starch-like intracellular particles. However, we also observed a broad distribution of the polysaccharide matrix without organisms. Fig. 1c shows a mucilage matrix, $7.1 \mu \mathrm{m}$ thick $(z)$ and several hundred $\mu \mathrm{m}$ long and wide $(x, y)$, originating from polysaccharide granules (intense fluorescence), which wind off in less fluorescent layers and strings. The latter are clearly visible in Fig. 1d, in which a polysaccharide layer $14 \mu \mathrm{m}$ thick 

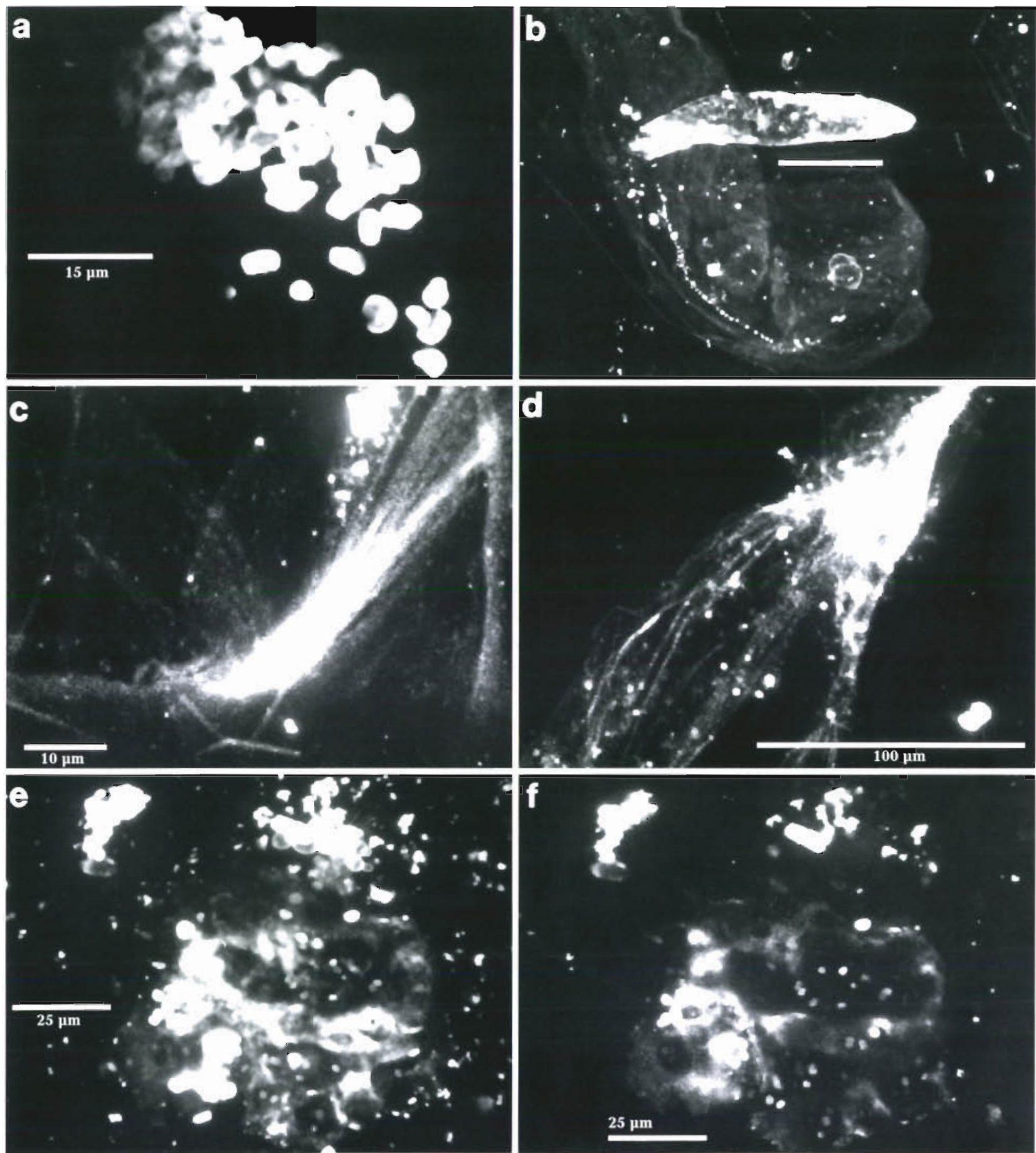

Fig. 1. SCLM images of fluorescent Con-A-FITC lectin bound to varıous morphological types of polysaccharides in mucilage specimens (a to d) and enrichment experiment $(e, f)$. (a) Intracellular polysaccharides (IPS) granules leaking from broken cells (upper left) in the mucilage. (b) Layers of exopolysaccharide (EPS) exuding from marine organisms packed with IPS granules in the mucilage (scale bar $=10 \mu \mathrm{m}$ ). (c) Polysaccharides constituting mucilage matrix. The highly dense fluorescence is due to polysaccharide granules winding off in layers and filaments. (d) Polysacchandes in the mucilage with dense fluorescent aggregates due to hıgh concentrations of polysaccharide granules winding off in strings. (e) Polysaccharide aggregation with globular fluorescence distribution similar to marine snow, obtained in the enrichment experiment. (f) Equatorial laser section of (e), showing empty interior of polysaccharide floc 
and more than $150 \mu \mathrm{m}$ wide showed distinct strings originating from a dense polysaccharide aggregate.

The size and morphology of polysaccharide structure in the mucilage were very different from those observed in marine snow flocs formed in the enrichment experiment. These experiments were designed to follow the microbial populations after addition of different nutrients (Malej et al. 1996). Con-A distribution imaged very dense flocs, especially when high concentrations of nutrients were added. In Fig. 1e, the morphology of a selected aggregate $(80 \mu \mathrm{m}$ wide $\times 20 \mu \mathrm{m}$ high) is shown. All flocs that developed in this control experiment had a globular shape with dispersed particulate polysaccharides and microbial aggregates. In an equatorial section of this floc at $6 \mu \mathrm{m}$ depth, internal hollow areas were observed (Fig. 1f). The type of geometry of polysaccharide aggregates in the enrichment experiment was completely different from that observed in the gel-like mucilage (Fig. 1d, e).

To verify these observations and demonstrate the specificity of the lectins for specific sugar residues, several side experiments were performed. Fig. 2a shows that Con-A binds partially to granules of hydrated amylopectin. When seawater swelled the granules, more sugar residues were available for binding Con-A. Conversely, the crystalline portion of the polysaccharide granule reacted feebly with the lectin. We used UEA-I which did not bind to amylopectin to demonstrate further that Con-A does not bind to all targets but only those with glucose available for binding (Fig, 2b).

Lectin UEA-I was also used to show the distribution of fucose, a minor constituent of mucilage (Murano et al. 1993, Faganeli et al. 1995). The UEA-I fluorescence distribution under the confocal microscope revealed few organisms characterized by an organized distribution of small fucose-containing particles on the cell envelope (Fig. 2C). Images of lysed cells of this kind showed only feeble globular fluorescence by UEA-I (Fig. 2d).

Extensive cell lysis in the mucilage was suggested by the use of another molecular probe, phalloidin. This low molecular weight fluorochrome is widely used to study cell cytoskeleton structures. Phalloidin binds preferentially to filamentous actin (F-actin), a ubiquitous protein in all eukaryotic cytoskeletons. In mucilage samples, we observed free exocellular F-actin without any cell structure in the vicinity (Fig. 2e) and associated with cell debris without envelopes (Fig. 2f).

Extensive cell lysis was evident in the mucilage especially for cylindrical diatoms, presumably belonging to Rhizosolenia fragilissima. The high frequency of this autotrophic organism was underestimated by optical microscopy since it was mostly associated with the optically dense amorphous matrix of the mucilage which was subsequently imaged with Con-A and confocal microscopy. However, other types of cell debris suggested massive destruction of diatom cells: empty envelopes with extruded cytoplasm (Fig. 3a), cell envelopes, partially disintegrated or without cytoplasm, forming thick polysaccharide strings (Fig. 3b).

Diatoms were also found in the enrichment experiment after $10 \mathrm{~d}$ and 1 mo of incubation with high concentrations of nutrients. Cell lysis of other species of organisms was not observed in either case. The only similarity with the large mucilage of the Adriatic Sea was the high concentrations of IPS granules (Fig. 3c).

Extensive cell lysis in the mucilage was confirmed by another fluorochrome, Nile red, which stains neutral lipids. These compounds were also stored in large amounts in marine organisms in the mucilage (Fig. 3d). Neutral lipids forming layers, with a geometric distribution similar to that of EPS, were also found outside cells (Fig. 3e). They were also found in layers in the matrix without adjacent eukaryotic cells. The lipids consisted of granules about the size of bacteria (Fig. 3f). In order to understand the significance of lipids in mucilage formation, their different classes were analyzed.

\section{Lipid biomarkers}

The complete lipid class distribution of mucilage is shown in Table 2 and Fig. 4. Lipids were present in detectable amounts in the Adriatic Sea mucus, and constituted $375 \mathrm{ng} \mathrm{g}^{-1}$ of its dry weight. Triacylglycerols (TAG), free fatty acids (FFA) and hydrocarbons (HC) were the most abundant lipid classes.

Enrichment experiment data over 10 d showed: a large increase in total suspended matter (from $1.88 \mathrm{mg} \mathrm{l}^{-1}$ to $5.00 \mathrm{mg} \mathrm{l}^{-1}$ ), particulate organic carbon (from $425 \mu \mathrm{g} \mathrm{l}^{-1}$ to $893 \mu \mathrm{g} \mathrm{l}^{-1}$ ), and dissolved organic carbon (from $113 \mu \mathrm{M}$ to $196 \mu \mathrm{M}$ ). These increases were accompanied by a significant decrease in total dissolved lipids $\left(35 \mu \mathrm{g} \mathrm{I}^{-1}\right.$ to $\left.5 \mu \mathrm{g} \mathrm{I}^{-1}\right)$ and an increase in total particulate lipids (34 $\mathrm{g} \mathrm{I}^{-1}$ to $276 \mu \mathrm{g} \mathrm{l}^{-1}$ ) or in suspended matter $\left(17.8 \mu \mathrm{g} \mathrm{g}^{-1}\right.$ to $\left.55.3 \mu \mathrm{g} \mathrm{g}^{-1}\right)$. Both control and nutrient-enriched experiment were characterized by large amounts of FFA, 20 and $162 \mu \mathrm{g} \mathrm{l}^{-1}$ (control) and 10480 and $32396 \mathrm{ng} \mathrm{g}^{-1}$ (enriched experiment) at $t=0$ and $t=10 \mathrm{~d}$ respectively, amounting to $59 \%$ of total lipids, a much higher proportion than found in mucilage (22\%) (Table 2 ).

The relative distributions of lipid classes (except FFA) in mucilage and in the control and nutrientenriched culture are shown in Fig. 5. Differences are evident between the mucilage material enriched with TAG, HC and alcohols and very depleted in sterols and polar lipids. 



Fig. 2. SCLM images with different molecular probes: (a) Con-A-FITC, (b to d) UEA-I-FITC lectins and (e, f) phalloidin-FITC, to evaluate their specificity and different scenarios in the mucilage sample. (a) Con-A bound to glucose residues of amylopectin of outer hydrated layers (high density fluorescence), detached from the crystalline granule core (feeble fluorescence of granule perimeter). (b) UEA-I did not bind to amylopectin. (c) UEA-I bound to fucose sugar residue of granules in this marine organism found in the mucilage. (d) UEA-I bound to fucose sugar residues of a broken organism showing faint globular shape of very different geometry to Con-A distribution in the mucilage. (e) Distribution of phalloidin bond to F-actin of a cell-free cytoskeleton belonging to a disintegrating organism in the mucilage. (f) Another residue of cytoskeleton without envelope imaged by phalloidin fluorescence 

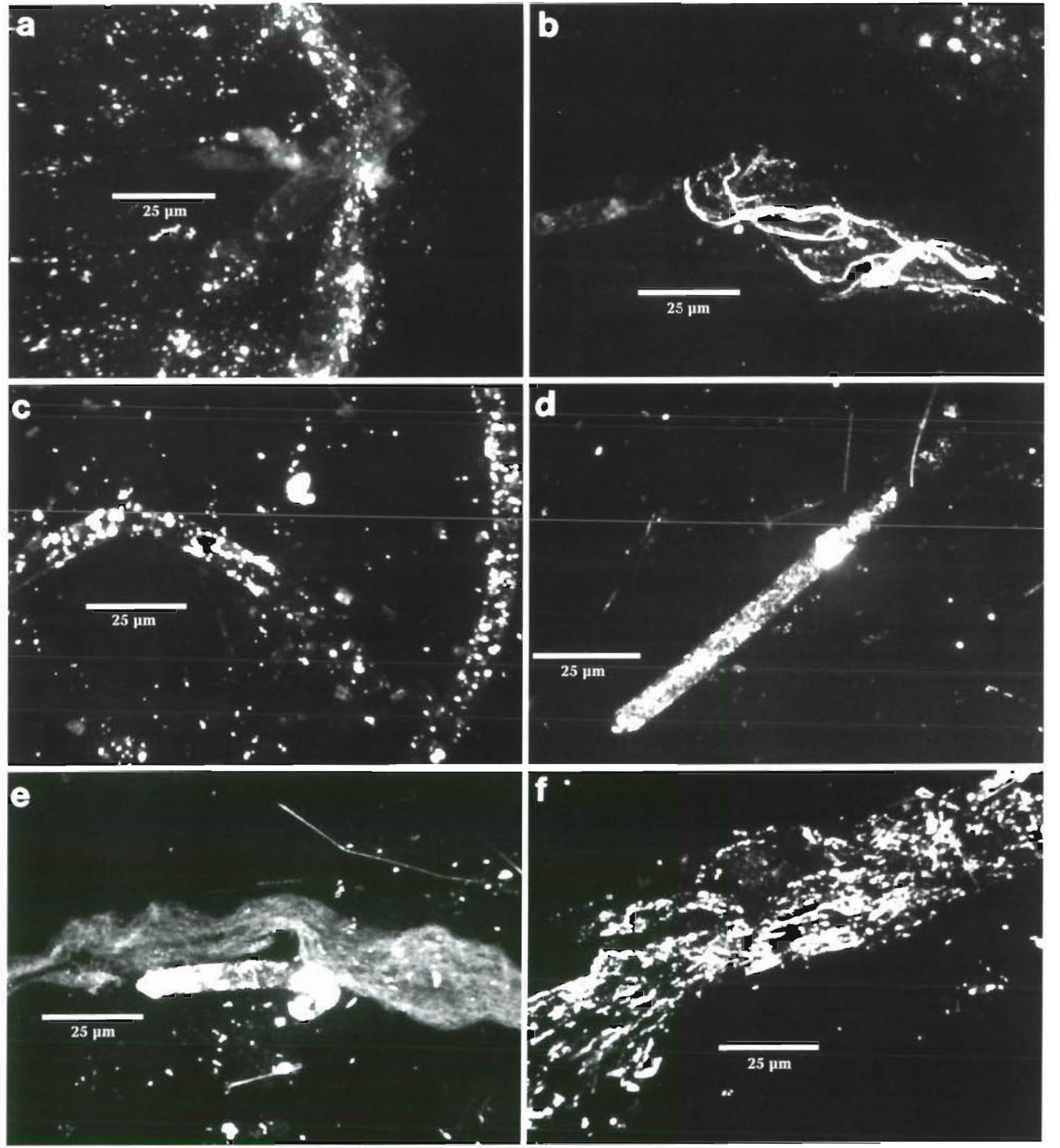

Fig. 3. Distribution of (a to c) Con-A and ( $d$ to f) Nile red fluorochrome in microorganisms embedded in the mucilage. (a) Lysed Rhizosolenja diatoms showing an empty cell envelope and leakıng IPS-rich cytoplasm. (b) Rhızosolenia diatoms with disintegratıng cell envelope (left) and cell residues (nght) producing polysaccharide strings. (c) Rhizosolenia diatom with high concentrations of IPS granules, but with intact envelope (no lysis) in the enrichment experiment at the end of the experiment (G). (d) Intact. cell of Rhizosolunia diatom with high concentrations of neutral lipids in the mucilage, imaged with Nile red fluorochrome. (e) Rhizosolenia diatom with high intracellular neutral lipids and densely fluorescent extracellular layer similar to polysaccharide stnngs. (f) Exocellular neutral lipid layer (without eukaryotic cells) imaged with Nile red 
Table 2. Distribution of lipid classes as measured by the latroscan method (in $\mathrm{ng} \mathrm{g}^{-1}$ of dry material and as \% of total lipids) for 1991 mucilage and for the enrichment experiment at $t=0$ and $t=10 \mathrm{~d}$. ALC: alcohols; FFA: free fatty acids; DAG: diacylglycerols; MAG(+PIG): monoacylglycerols (+ pigments); ME: methyl esters; TAG: triacylglycerols; SE: sterol esters; ST: sterols; DPG + PG: diphosphatidylglycerols + phosphatidylglycerols; PE: phosphatidylethanolamines; 2 PL: polar lipids (DPG + PG + PE); PIG: pigments; HC: hydrocarbons

\begin{tabular}{|c|c|c|c|c|c|c|c|}
\hline & & \multirow{2}{*}{\multicolumn{2}{|c|}{ Mucilage }} & \multicolumn{4}{|c|}{ Enrichment experiment } \\
\hline & & & & \multicolumn{2}{|c|}{$t=0$} & \multicolumn{2}{|c|}{$t=10 \mathrm{~d}$} \\
\hline & & $\mathrm{ng} \mathrm{g}^{-1}$ & $\%$ & $n g g^{-1}$ & $\%$ & $n g g^{-1}$ & $\%$ \\
\hline \multirow[t]{5}{*}{ Degradation lipids } & ALC & 25 & 7 & 138 & 1 & & \\
\hline & FFA & 84 & 22 & 10480 & 59 & 32396 & 59 \\
\hline & DAG & 8 & 2 & & & 1758 & 3 \\
\hline & MAG $1+$ PIG at $t=10 \mathrm{~d}$ ) & 8 & 2 & 714 & 4 & 3391 & 6 \\
\hline & $\mathrm{ME}$ & 13 & 3 & 815 & 5 & 988 & 2 \\
\hline \multirow[t]{2}{*}{ Storage lıpids } & TAG & 111 & 30 & 1297 & 7 & 2149 & 4 \\
\hline & SE & 12 & 3 & 53 & 0 & 824 & 1 \\
\hline Structural lipids & ST & 26 & 7 & 1670 & 9 & 5365 & 10 \\
\hline Lipids associated with & $D P G+P G$ & & & 1384 & 8 & 6060 & 11 \\
\hline \multirow[t]{4}{*}{ living biomass } & $P E$ & & & 361 & 2 & 389 & 1 \\
\hline & $\sum P L$ & 8 & 2 & & 10 & & 12 \\
\hline & PIG & 1 & 0.3 & 282 & 2 & & \\
\hline & $\mathrm{HC}$ & 78 & 21 & 638 & 4 & 1963 & 4 \\
\hline Total lipids & & 375 & 100 & 17833 & 1.00 & 55282 & 100 \\
\hline
\end{tabular}

\section{DISCUSSION}

The mucilage is a large heterogeneous prevalently polysaccharide matrix (Marchetti et al. 1989. Murano et al. 1993) in which many autotrophic and heterotrophic prokaryotic and eukaryotic cells are embedded. The most abundant microorganisms revealed by epifluorescence and light transmission microscopy in the July 1991 sample were the diatom Cylindrotheca closterium, Synechococcus-like cyanobacteria and heterotrophic bacteria.

The molecular probes Con-A and UEA-I made it possible to observe the distribution of different types of polysaccharides. In the mucilage Con-A revealed particulate polysaccharides containing glucose and/or mannose, which are widespread in many marine organisms (Ittekott et al. 1982, Bertocchi et al. 1990, Compiano et al. 1993, Saliot 1994).

The lectin UEA-I predominantly labeled dinoflagellate species, and most of the organisms were not fluorescent, unlike with Con-A. Fucose was less widespread in the mucilage, which is in line with the known chemical composition of the mucilage (Murano et al. 1993, Faganeli et al. 1995). The fact that fucose distribution was different from that of sugar residues labeled by Con-A confirmed the specificity of the lectins. On the other hand, Nile red fluorochrome showed high intracellular and extracellular concentrations of neutral lipids. These 2 findings are probably related to a lack of balance between the $C$ source and nutrient availability in the environment during the mucilage event. However, the important observation was the leaking of IPS granules from lysed diatoms, especially Rhizosolenia fragilissima. Many diatom cells were broken or disintegrating and naked cell cytoplasms were free in the mucilage, separated from their cell envelopes. Some envelopes of $R$. fragilissima had completely dissolved, producing polysaccharide strings and filaments. This cell lysis was also observed by fluorescent labeling of cytoskeletal F-actin with phalloidin. The free cell structures observed are clear evidence of cell deterioration. These aspects were undetectable by conventional microscope analysis: their observation has been made possible by highly specific fluorescent molecular probes.

Extensive cell lysis cannot be ascribed to storage of the material in formalin for 3 yr. Storage in formalin is associated with changes in protein structure and pigment fading, but it does not provoke cell disruption (Hall 1991).

Lipid analysis of freeze-dried mucilage indicated cell deterioration. Comparison of lipid classes in mucilage and phytoplankton in the enrichment experiment provided additional evidence that the mucilage could be a product of cell lysis. Fig. 5 shows that large quantities of triacylglycerols (TAG) were found in mucilage with respect to the enrichment experiment. TAG are energy storage compounds and are known to accumulate in senescent phytoplankton cells (Parrish \& Wangersky 1987). TAG abundance has been shown to increase progressively from 9 to $40 \%$ of total lipids in cultures of Nannochloropsis salina and Pavlova lutheri during the 


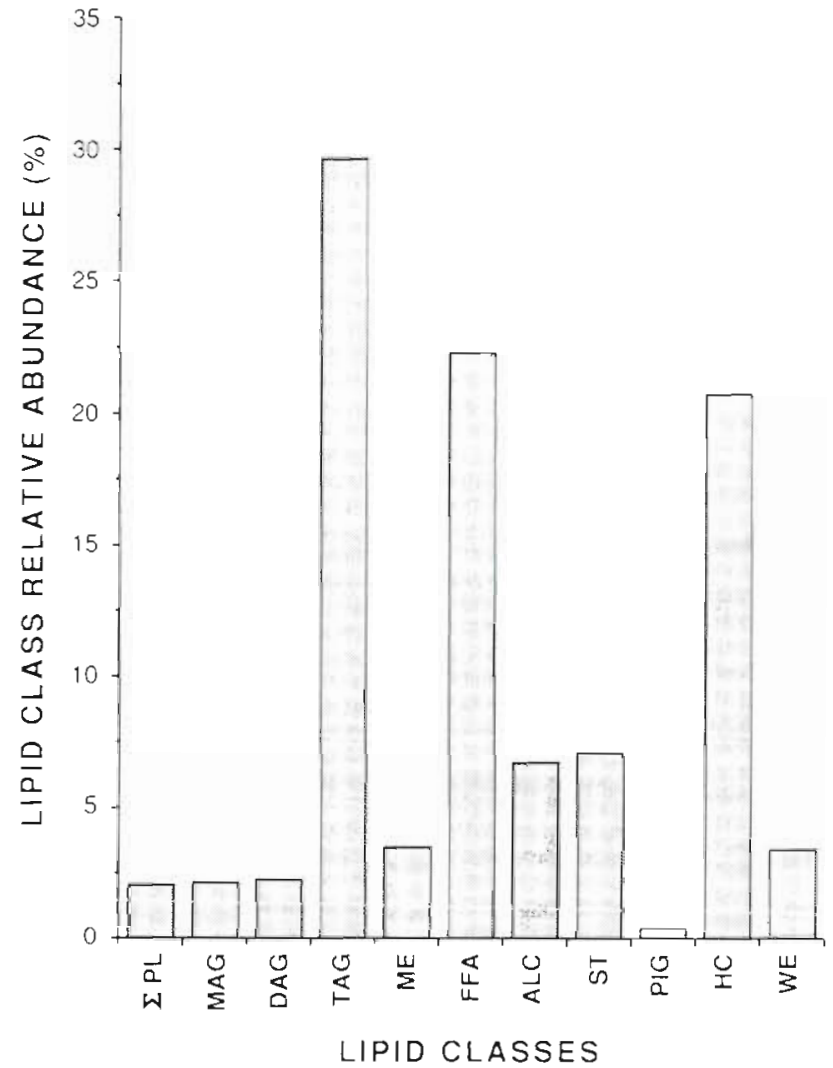

Fig. 4. 1991 muclage sample: distribution of lipid classes (percentage of total lipids) analyzed by the latroscan technique. $\sum$ PL: sum of polar lipids (diphosphatidylglycerols + phosphatidylglycerols + phosphatıdylethanolamines + phosphatidylcholine); MAG: monoacylglycerols; DAG: diacylglycerols; TAG: triacylglycerols; ME: methyl esters; FFA: free fatty acids; ALC: alcohols; ST: free sterols; PIG: pigments; $\mathrm{HC}$ : hydrocarbons; WE: wax esters lysis of ester bonds. In coastal areas they can also arise from terrigenous inputs. Although often of man-made origin, hydrocarbons (HC) are also components of zooplankton, microalgae and other microorganisms, in which they can constitute up to $10 \%$ of total lipids (Saliot 1981, Parrish 1988). HC are more refractory than fatty acids, and tend to accumulate preferentially. Some exceptionally high proportions have been recorded in phytoplankton, for example up to $80 \%$ of total lipids in Botryococcus braunii. Emdadi \& Berland (1989) studied the evolution of lipid class composition during the different phases of growth of 2 microalgae. When harvested in the lag phase, $\mathrm{HC}$ in Nannochloropsis salina and Pavlova lutheri were 78 and $48 \%$ of total lipids, respectively, but less than $5 \%$ of total lipids in the exponential phase.

Strong evidence of cell lysis and of the highly degraded character of the mucilage material is obtained from its polar lipid (PL) content. PL consist mainly of phospholipids and glycolipids, which are structural components of cell and chloroplast membranes and are continually renewed in living cells (Parrish 1988). They can therefore be regarded as biomarkers of the living component of organic matter. PL predominate over other lipid classes in phytoplankton cells grown under favourable conditions (Volkman \& Nichols 1991) and in oceanic bacteria (Goutx et al. 1990). In the Adriatic mucilage, PL were less abundant than in any material reported in the literature: $2 \%$ of total lipids (Table 2), much less than in the enrichment experiment where PL accounted for 10 to $12 \%$ of total lipids. Moreover free fatty acids (FFA) were only $22 \%$ of total lipids in the mucilage compared to $59 \%$ in the enriched experiment. The value recorded in the mucilage is slightly below the $25 \%$ level that Parrish (1988) recommends as indicative of in situ degradation. The very high stationary phase (Emdadi \& Berland 1989). Suen et al. (1987) reported higher levels of TAG in nitrogen-deficient cultures of Nannochloropsis (79\% of total lipids).

In the Adriatic mucilage, TAG constituted $30 \%$ of total lipids; a lower value was found for particulate material collected in spring and summer in the Scotian slope area (from 14 to $25 \%$ ) (Parrish et al. 1988) and for particulate material collected in early and late summer in the northern Adriatic (from 16 to $18 \%$ ) (Derieux et al. 1997). Higher levels of degradation products such as hydrocarbons and alcohols were observed in the mucilage than in the enrichment experiment (Fig. 5). Linear alcohols (ALC) are produced during the



Fig. 5. Lipid class distribution (percentage of total lipids minus free fatty acids) of significant pools in mucilage and enrichment experiment cultures analyzed at different times $(t=0$ and $t=10 \mathrm{~d}$ ). Abbreviations as in Fig. 4 
value encountered in the enrichment experiment may be explained by large amounts of phaeophytins (Cauwet et al. 1997), indicating the presence of senescent cells.

FFA are minor components of algae and are produced mostly during the growth phase (Emdadi \& Berland 1989, Volkman \& Nichols 1991). However, FFA are more abundant in diatoms than in other algae, reaching values up to $79 \%$ of total lipids (Goutx et al. 1990). Extracellular FFA released in phytoplankton cultures accounted for 10 to $20 \%$ of total lipids (Parrish \& Wangersky 1987). In productive natural waters, dissolved FFA often exceed the values measured in phytoplankton cultures. During the spring bloom in the North Sea, Kattner et al. (1983) reported that FFA abundance varied between 40 and $54 \%$ of total lipids. Likewise, FFA were from 5 to $35 \%$ of dissolved lipids in spring and summer over the Scotian shelf (Parrish et al. 1988).

The mucilage was difficult to study by light microscopy because of the complex optically dense matrix of the sample. It has been suggested that polysaccharide mucilage is a product of anomalous algal exudation of EPS (Fogg 1995); however, its gel-like structure suggests that other mechanisms are involved. The consistency and mechanical resistence of this mucilage indicate transformation of the particulate polysaccharides into a jelly-like substance. Freeze-dried samples, thawed and resuspended in seawater, maintained their jelly structure even after $5 \mathrm{yr}$ of storage ( $\mathrm{V}$. Turk pers obs.).

Confocal microscope and molecular probe Con-A images of the distribution of polysaccharides in the mucilage indicated leakage of IPS granules from lysed cells and disintegration of cell envelopes. These 2 events are probably the main polysaccharide sources involved in mucilage events in the Adriatic Sea, together with the transparent exopolymer particles (TEP) formed by coalescence of EPS (Passow et al. 1994) and cell exudation (Herndl 1992, Hoagland et al. 1993). EPS exudation provoked by nutrient stress was studied in the enrichment experiment with prokaryotes and eukaryotes (Malej et al. 1997) in the northern Adriatic. Fibrils and layers of polysaccharides similar to those observed in the mucilage were never obtained.

When pure commercial polysacccharides such as amylopectin particles are suspended in seawater they do not dissolve; a partial hydration of the granule occurs after few days, but no jelly forms. The formation of gel-like mucilage in the Adriatic Sea probably involves several processes. Fibrils and layers in the mucilage matrix are probably formed by reaction of ionic polysaccharides with cations such as $\mathrm{Ca}^{2+}$ (Rees et al. 1982, Leppard 1995) which makes the mucilage dense and resistant to mechanical disruption.
Jelly could be formed by interactions between polysaccharides and lipids and their acylglycerol derivates. Lipopolysaccharides (LPS) are sometimes exudation products of bacteria (Decho 1990, Schnaitman \& Klena 1993), but the main source of LPS in mucilage is probably the degradation of cell membranes and the association of polysaccharides and lipids as storage materials.

Hydration of the polysaccharides and consolidation with metals and/or lipids produces a physical-chemical resistance of the mucilage to microbial attack. Degradation may then only be successful in late summer, when the mucus settles to the bottom and comes into contact with the more abundant benthic microbial community (Herndl et al. 1987).

At the moment we cannot explain cell lysis in the mucilage of the Adriatic Sea. One hypothesis is a virus attack, since virus-like particles were found by transmission electron microscopy (data not shown) in broken cells. This hypothesis is supported by the fact that large amounts of polysaccharides were produced in the bioreactor when the microalga Phaeocystis pouchetii was infected with PPV virus for $48 \mathrm{~h}$ (M. Heldal \& F. Baldi pers. comm.). Another hypothesis is that lytic compounds with surfactant properties may occasionally be formed during the algal bloom. Lipids conjugated to polysaccharides are good amphipathic emulsifiers (Dasai \& Banat 1997). However, these 2 hypotheses are not incompatible with others formulated previously: (1) formation of a thick false benthos at the pycnocline (Herndl 1992); (2) nutrient imbalance and carbon storage accumulation followed by anomalous EPS exudation (Fogg 1995); (3) formation of microbial aggregates due to persistent blooms caused by efficient $P$ remineralization and carbon storage (Azam 1997). These hypotheses do not explain extensive cell lysis but raise the question of whether cell disruption occurs before or after aggregation of marine organisms. For the answer to this question, we shall have to await the next mucilage event in the northern Adriatic Sea.

Acknowledgements. We thank G. Cauwet for organic carbon analysis and $J$. Flllaux for Iatroscan analysis. This research was undertaken in the framework of the PALOMA programme. We acknowledge the support of the Commission of the European Community Environment R \& D programme, under contract CEE-5EV-CT94-0420 and PECO under contract ERBCIPD-CT94-0106. The research was also supported by the Ministry of Science and Technology of the Republic of Slovenia. The authors also thank Farooq Azam and Cindy Lee for their critical reviews of the manuscript and constructive comments.

\section{LITERATURE CITED}

Alldredge AL, Jackson GA (1995) Topical studies in oceanography. Aggregation in marine systems. Deep Sea Res 42: $273-275$ 
Alldredge AL, Passow U, Logan BE (1993) The abundance and significance of a class of large, transparent organic particles in the ocean. Deep Sea Res 40:1131-1140

Azam F (1997) Possible cause of massive mucilage production in the northern Adriatic sea: a novel hypothesis. In: Physical and biogeochemical processes of the Adriatic Sea: eutrophic limits of the northern Adriatic. In: Nolan C (ed) The Adriatic Sea. European Communities Ecosystems Research Reports Series, Brussels (in press)

Bertocchi CL, Navarini A, Cesaro F (1990) Polysaccharides from cyanobacteria. Carbohydr Polymers 12:127-153

Cauwet G, Terzlc S, Ahel M. Mozetic P, Turk V, Malej A (1997) Effect of nutrient addition on phytoplankton/bacterioplankton interactions and dissolved organic matter variability. Part II: Biochemical aspect. In: Physical and biogeochemical processes of the Adriatic Sea: eutrophic limits of the northern Adriatic. In: Nolan C (ed) The Adriatic Sea. European Communities Ecosystems Research Reports Series, Brussels (in press)

Compiano AM, Romano JC, Garabetian F, Laborde $P$, Giraudiere I (1993) Monosaccharide composition of particulate hydrolysable sugar fraction in surface microlayers from brackish and marine waters. Mar. Chem 42:237 251

Decho AW (1990) Microbial exopolymer secretions in ocean environments: their role(s) in food webs and marine processes. Oceanogr Mar Biol Annu Rev 28:73-153

Degobbis D, Fonda-Umani S, Franco P, Malej A, Precali R, Smodlaka N (1995) Changes in the northern Adriatic ecosystem and the hypertrophic appearance of gelatinous aggregates. Sci Total Environ 165:43-58

Derieux S, Moine F. Fillaux J, Pinturier L, Jan G, Laurelllard J. Saliot A (1997) Lipid chemistry of particulate and dissolved organic matter in the North Adriatıc in September 1994 and June 1995. In: Nolan C (ed) The Adriatic Sea European Communities Ecosystems Research Reports Series, Brussels (in press)

Desai JD, Banat IM (1997) Microbial production of surfactants and their commercial potential. Microbiol Mol Biol Rev 61 $47-64$

Emdadı D, Berland B (1989) Variation in lipid class composition during batch growth of Nannochloropsis salina and Pavlova lutheri. Mar Chem 26:215-225

Faganeli J, Kovac N, Leskovsek H, Pezdic J (1995) Sources and flux of particulate organic matter in shallow coastal waters characterized by summer macroaggregate formation. Biochemistry 29:71-88

Fogg GE (1995) Some speculations on the nature of the pelagic mucilage community of the northern Adriatic Sea. Sci. Total Environ 165:59-64

Fonda Umani S, Ghırardelli E, Specchı EM (1989) Glı episodi di mare sporco nell'Adriatico dal 1729 ai glorni nostri. Regione Autonoma Friuli-Venezia Giulia. Direzıone regionale dell'Ambiente, Trieste

Gabius HJ, Gabius S (1993) Lectins and glycobiology Springer-Verlag Inc, New York

Goutx M. Gerin C, Bertrand JC (1990) Lipid classes of microorganisms as biomarkers in the marine environment. Org Geochem 16:231-237

Greenspan P, Fowler SD (1985) Spectrofluorometric studies of the lipid probe. Nile red. J Lipid Res 26:781-789

Hall JA (1991) Long term preservation of picophytoplankton for counting by fluorescence microscopy. Br Phycol J 26:169-174

Haugland RP (1992) Handbook of fluorescent probes and research chemicals, Larison $\mathrm{KD}$

Herndl GJ (1992) Marine snow in the northern Adriatic Sea: possible causes and consequences for a shallow ecosystem. Mar Microbial Food Webs 6(2):149-172
Herndl GJ, Faganeli J, Fanuko N, Peduzzi P, Turk V (1987) Role of bacteria in the carbon and nitrogen flow between watercolumn and sediment in a shallow marine bay (Bay of Piran, northern Adnatic Sea). PSZN L: Mar Ecol 8(3):221-236

Hoagland KD, Rosowski JR, Gretz MR, Romer SC (1993) Diatom extraceliular polymeric substances: function, fine structure, chemistry and physiology. J Phycol 29:537-566

Ittekott V, Degens ET, Brockmann U (1982) Monosaccharide composition of acid-hydrolysable carbohydrates in particulate matter during a phytoplankton bloom. Limnol Oceanogr 27:770-776

Kattner G, Gercken G, Hammer KD (1983) Development of lipids during a spring plankton bloom in the northern North Sea. II. Dissolved lipids and fatty acids. Mar Chem $14: 163-173$

Kiørboe T, Hansen LS (1993) Phytoplankton aggregate formation: observations of patterns and mechanisms of cell sticking and the significance of exopolymer material J Plankton Res 15:993-1018

Laureillard J, Pinturier L, Fillaux J, Saliot A (1997) Organic geochemistry of marine sediments of the Subantarctic Indian Ocean sector lipid classes, sources and fate. Deep Sea Res (in press)

Leppard GG (1995) The characterization of algal and microbial mucilages and their aggregates in aquatic ecosystems. Sci Total Environ 165:103-131

Malej A, Mozetic P. Turk V, Terzic S, Ahel M, Cauwet G (1997) Effect of nutrient addition on phytoplankton/bacterioplankton interactions and dissolved organic matter variability. Part I: Productivity aspect. In: Physical and biogeochemical processes of the Adriatic Sea: eutrophic limits of the northern Adriatic. In: Nolan C (ed) The Adriatic Sea. European Communities Ecosystems Research Reports Series, Brussels (in press)

Marchetti R, Iacominı M, Torri G, Focher B (1989) Caratterizzazione preliminare degli essudati di origine planctonica raccolt in Adriatico nell'estate 1989. Acqua Aria 8: $883-887$

Murano E, Vetere A, Toffanin R, Liuti G, Sandri G, Rizzo R (1993) Characterization of the complex mucilage produced by marine microorganisms. Atti Soc Italiana Biochimica (SIB) Trieste 9

Myklestad SM (1995) Release of extracellular products by phytoplankton with special emphasis on polysaccharides. Sci Total Environ 165:155-164

Neu TR, Marshall KC (1991) Microbial 'footprints'-a new approach to adhesive polymers. Biofouling 3:101-112

Parrish CC (1988) Dissolved and particulate marine lipid classes: a review. Mar Chem 23:17-40

Parrish CC, Wangersky PJ (1987) Particulate and dissolved lipid classes in cultures of Phaeodactylum tricornutum grown in cage culture turbidostats with a range of nitrogen supply rates. Mar Ecol Prog Ser 35:119-128

Parrish CC, Wangersky PJ, Delmas RP, Ackman X (1988) Iatroscan-measured profiles of dissolved and particulate marine lipld classes over the Scotian Slope and in Bedford Basin. Mar Chem 23:1-15

Passow U, Logan BE, Alldredge AL (1994) The role of particulate carbohydrate exudates in the flocculation of diatoms blooms. Deep Sea Res 41:335-357

Porter KG, Feig YS (1980) The use of DAPI for identifying and counting aquatic microflora. Limnol Oceanogr 25:943-948

Rees DA, Morris ER. Thom D, Madden JK (1982) Shapes and interactions of carbohydrate chains In: Aspinall GO (ed) The polysaccharides. Academic Press, New York, p 195-290 
Saliot A (1981) Natural hydrocarbons in seawater. In: Duursma EG, Dawson R (eds) Marine organic chemistry. Elsevier, Amsterdam, p 327-374

Saliot A (1994) Hydrates de carbone et polysaccharides In: Biogéochimie organique marine. Océanis 20:111-135

Saliot A, Laureillard J, Scribe P, Sicre MA (1991) Evolutionary trends in the lipid biomarker approach for investigating the biogeochemistry of organic matter in the marine environment. Mar Chem 36:233-248

Schnaitman CA, Klena JD (1993) Genetics of lipopolysaccharide biosynthesis in enteric bacteria. Microbiol Rev 57: $655-682$

Stachowitsch M, Fanuko N, Richter M (1990) Mucus aggregates in the Adriatic Sea: an overview of stages and occurrences. PSZN 1: Mar Ecol 11:327-350

Suen Y, Hubbard JS, Holzer G, Tornabene TG (1987) Total lipid production of the green alga Nannochloropsis sp QII under different nitrogen regimes. J Phycol 356:147-162

Takahashi M. Kikuchi K, Hara Y (1985) Importance of picocyanobacteria biomass (unicellular blue-green algae) in the phytoplankton population of the coastal waters of Japan. Mar Biol 89:63-69

Utermöhl H (1958) Zur Vervollkommnung der quantitativen Phytoplankton-Methodik. Mitt Int Verein Theor Angew Limnol 9:1-38

This article was presented by F. Azam, La Jolla, Callfornia, USA
Viviani $R$, Boni L, Cattani O, Milandrı A, Pirini M, Polettı $R$, Pompei M (1995) Fatty acids, chiorophylls and total silicon in mucilaginous aggregates collected in a coastal area of the northern Adriatic Sea facing Emiliana-Romagna in August 1988. Sci Total Environ 165:193-201

Volkman JK, Everitt DA, Aallen DI (1986) Some analyses of lipid classes in marine microorganisms, sediments and seawater using thin-layer chromatography flame ionisation detection. J Chromatogr 356:147-162

Volkman JK, Nichols PD (1991) Application of thin layer chromatography-flame ionization detection to the analysis of lipids and pollutants in marine and environmental samples. J Plan Chromatogr 4:19-26

Vollenweider RA, Montanari G. Rinaldi A (1995) Statistical inferences about the mucilage events in the Adriatic Sea, with special reference to recurrence patterns and claimed relationships to sun activity cycles. Sci Total Environ 165: $213-225$

Wakeham SG, Lee C (1989) Organic geochemistry of particulate matter in the ocean: the role of particles in oceanic sedimentary cycles. Org Geochem 14:83-96

Wolfaardt GM, Lawrence JR, Robarts RD, Caldwell SJ, Caldwell DE (1994) Multıcellular organization in a degradative biofilm community. Appl Environ Microbiol 60: $434-446$

Manuscript first received: October 12, 1996

Revised version accepted: April 16, 1997 